\section{Accumulation of a 60-kD Dehydrin Protein in Peach Xylem Tissues and Its Relationship to Cold Acclimation}

\author{
Rajeev Arora ${ }^{1}$ \\ Division of Plant and Soil Sciences, West Virginia University, Morgantown, \\ WV 26506 \\ Michael Wisniewski ${ }^{2}$ \\ U.S. Department of Agriculture, Agricultural Research Service, Appalachian \\ Fruit Research Station, Kearneysville, WV 25430
}

Additional index words. Prunus persica, deep supercooling, cryoprotective proteins

\begin{abstract}
The seasonal pattern of dehydrin accumulation was characterized during cold acclimation and deacclimation in the xylem tissues of genetically related (sibling) deciduous and evergreen peach (Prunus persica $\mathrm{L}$.). Immunological studies indicate that a 60-kD polypeptide in peach xylem tissues is a dehydrin protein. Comparison of its accumulation pattern with seasonal fluctuations in cold hardiness indicate that dehydrin accumulated to high levels during the peak of cold acclimation. However, its accumulation was only weakly associated with cold hardiness during early stages of cold acclimation and during deacclimation. Our results indicate that factors related to supercooling rather than dehydrin accumulation may be primarily responsible for determining levels of cold hardiness during transition periods.
\end{abstract}

Living xylem tissues of many temperate hardwoods, including deciduous fruit trees, survive freezing temperatures by deep supercooling, an avoidance mechanism (Ashworth and Wisniewski, 1991; George et al., 1982; Quamme, 1976; Wisniewski and Arora, 1993). In contrast, bark and leaf tissues survive freezing stress by tolerating the dehydrative stress and cell collapse that result from the loss of cellular water to extracellular ice (Ashworth and Wisniewski, 1991; Wisniewski and Arora, 1993). Wisniewski (1995) recently reviewed deep supercooling in woody plants.

As with other factors involved in cold acclimation, evidence indicates that a distinct seasonality in the expression of deep supercooling exists that determines cold acclimation and deacclimation in xylem tissues of temperate hardwoods (Burke et al., 1979). Seasonal variation in deep supercooling has been documented for peach xylem tissues (Arora et al., 1992; Ashworth et al., 1983). Recently, we provided evidence for a relationship between quantitative and qualitative fluctuations of several polypeptides and the cold hardiness of xylem tissues of sibling decidu-

Received for publication 6 May 1996. Accepted for publication 12 June 1996. We acknowledge the technical support of Wilbur Hershberger and Glen Davis. Financial support for this work was supported by U.S. Dept. of Agriculture-Agricultural Research Service. The cost of publishing this paper was defrayed in part by the payment of page charges. Under postal regulations, this paper therefore must be hereby marked advertisement solely to indicate this fact.

${ }^{1}$ Assistant Professor.

${ }^{2}$ Plant Physiologist; to whom reprints requests should be addressed. ous and evergreen peach genotypes (Arora et al., 1992). However, these proteins were not identified. Subsequently, we identified a 60$\mathrm{kD}$ dehydrin protein in peach bark (PCA 60), which is associated with seasonal changes in the level of cold hardiness (Arora and Wisniewski, 1994). Muthalif and Rowland (1994) have also reported the presence of dehydrin-like proteins that were associated with chill unit accumulation in floral buds of blueberry (Vaccinium corymbosum L. and V. ashei Reade).

Dehydrins are glycine-rich, hydrophilic, heat-stable proteins and are generally induced in response to a wide array of environmental stresses (low temperature, water stress, osmotic stress) having cellular dehydration as a common induction factor (Close et al., 1993). The objective of this study was to determine whether the $60-\mathrm{kD}$ dehydrin protein is present and associated with seasonal fluctuations in cold hardiness in peach xylem tissues. Additionally, seasonal patterns of its accumulation in sibling deciduous and evergreen peach were compared.

\section{Materials and Methods}

Current-year shoots were collected randomly at monthly intervals (August through May) from four to five trees each of 2-year-old sibling deciduous and evergreen peach at the Appalachian Fruit Research Station, Kearneysville, W.Va. Sibling populations of deciduous and evergreen peach (in $\mathrm{F}_{2}$ generation) resulted from selfing of $F_{1}$ trees of Empress dwarf (deciduous) X P.I. 442380 (evergreen) (Arora et al., 1992). Pooled samples were packed on ice and brought to the laboratory. Bark from collected samples was scraped with a razor blade. Debarked samples were rinsed with deionized water and stored at -80 ${ }^{\circ} \mathrm{C}$ until used for protein extraction. Xylem proteins were extracted from lyophilized and powdered tissue as described by Arora et al. (1992). Sample preparation, sodium dodecyl sulfate polyacrylamide-gel electrophoresis (SDS-PAGE), and electroblotting of protein were performed as previously described (Arora et al., 1992; Arora and Wisniewski, 1994). Electroblotted proteins were probed with a 1:1000 dilution of anti-dehydrin antiserum (kindly provided by Timothy Close). Seasonal cold hardiness values $\left(\mathrm{LT}_{50}\right.$, based on the electrolyte leakage method) used in this study were derived from a previous study using the same samples, where we showed that seasonal $\mathrm{LT}_{50}$ values were strongly correlated $(r=0.99)$ with the midpoint of seasonal low-temperature exotherms, as determined by differential thermal analysis (DTA) (Arora et al., 1992).

\section{Results and Discussion}

Immunoblot data indicated a distinct seasonal pattern of accumulation of $60-\mathrm{kD}$ dehydrin protein in the xylem tissues of both genotypes (Fig. $1 \mathrm{~A}$ and B). This protein became prominent in November, accumulated to high levels in January, and decreased during spring in deciduous peach. It was undetected in May. In the evergreen trees, it became prominent in November (at relatively lower levels than in deciduous trees), stayed at about the same level through January, and was not detectable from February onwards. Hence, the protein was present in higher amounts and for longer duration in the xylem tissues of the deciduous genotype than in the evergreen genotype (Fig. 1 A and B).

The seasonal patterns of accumulation of the $60-\mathrm{kD}$ dehydrin protein paralleled the seasonal fluctuations of cold hardiness $\left(\mathrm{LT}_{50}\right)$ in the two genotypes (Fig. $1 \mathrm{~A}$ and $\mathrm{B}$ ). The association of $60 \mathrm{kD}$ protein with cold hardiness in xylem tissue, however, was not as strong as was previously reported for bark tissues (Arora et al., 1992). In deciduous trees, in addition to $60 \mathrm{kD}$ polypeptide, accumulation of other dehydrin-like proteins (ranging from 30 to $50 \mathrm{kD}$ ) also was evident during winter months (Fig. 1A). These proteins were not present in evergreen siblings (Fig. 1B). This pattern is consistent with seasonal profiles of soluble proteins from xylem tissues of the two genotypes (Arora et al., 1992), which indicated more protein bands present in this range in deciduous trees than in the evergreens during winter months.

Results from this study and from our previous work (Arora et al., 1992; Wisniewski and Ashworth, 1986) indicate that cold acclimation in xylem tissues of peach is a physiologically dynamic process and that altered expression of specific, stress-induced proteins may be associated with cold acclimation in peach xylem tissues. Although the fluctuations in the $\mathrm{LT}_{50}$ and dehydrin accumulation are associated, they do not exactly mirror each other. For example, the $\mathrm{LT}_{50}$ of xylem tissues of the deciduous genotype increased from $-11.0^{\circ} \mathrm{C}$ (August) to $-22.0^{\circ} \mathrm{C}$ (October) before any 


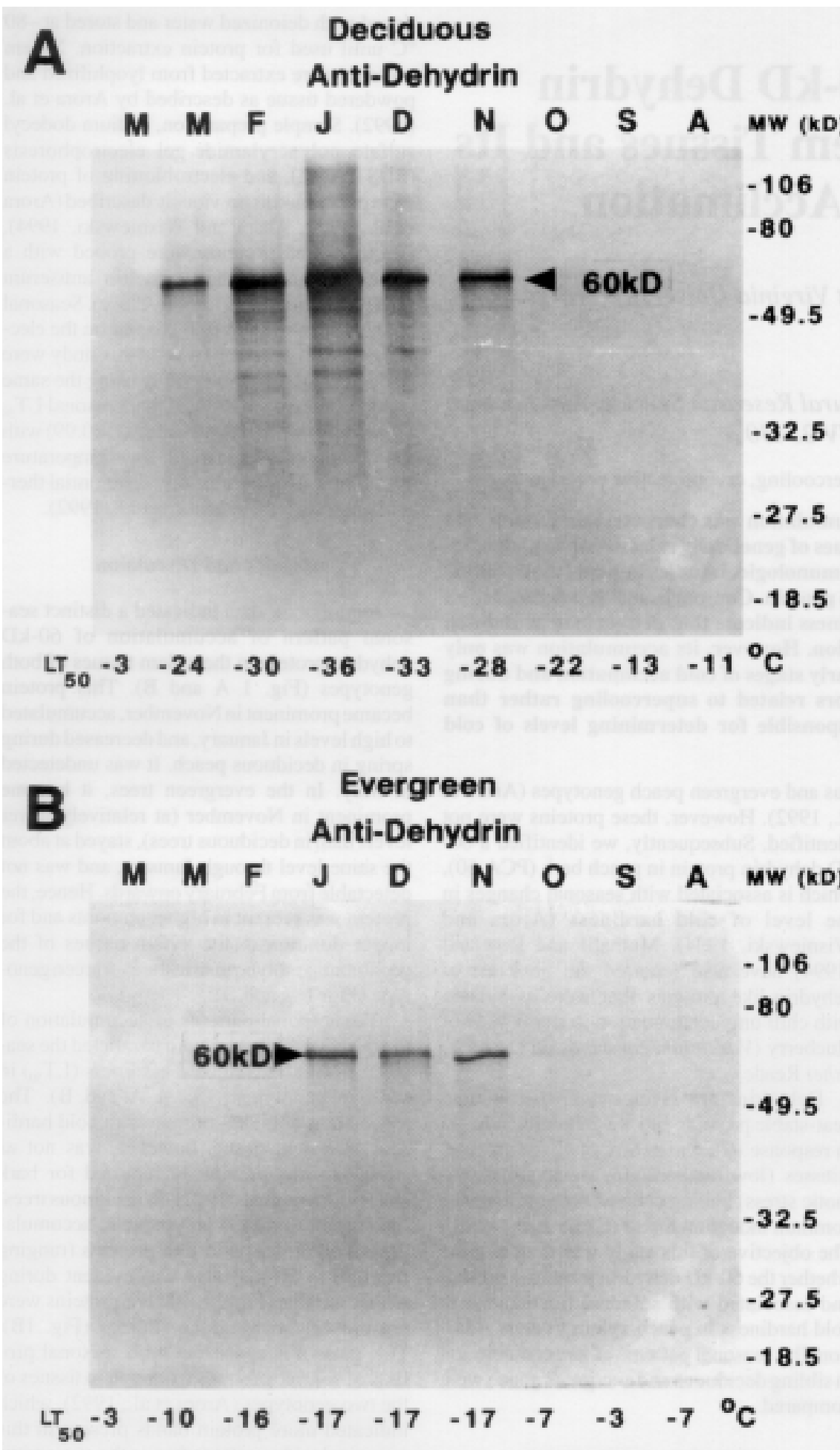

Fig. 1. Seasonal variation in the accumulation of $60-\mathrm{kD}$ dehydrin protein and cold hardiness in the xylem tissues of sibling $(\mathbf{A})$ deciduous and $(\mathbf{B})$ evergreen peach genotypes. Five micrograms of protein per line from SDS-PAGE was transferred on nitrocellulose membrane and probed with anti-dehydrin antiserum. Letters above each lane (right to left) denote successive monthly samples from August through May, except for April. Corresponding cold hardiness values $\left(\mathrm{LT}_{50}\right)$ are listed at the bottom of each lane. Molecular weight markers are shown on the right.

dehydrin accumulation (Fig. 1A). In contrast, in the evergreen genotype, the $\mathrm{LT}_{50}$ gradually decreased from $-16.0^{\circ} \mathrm{C}$ (February) to $-3.0^{\circ} \mathrm{C}$ (May), although dehydrins were completely absent. Dehydrins accumulated to maximum levels during the height of cold acclimation in both genotypes but were only weakly associated with the cold hardiness during early stages of cold acclimation and deacclimation. This suggests that the ability to deep supercool may be primarily responsible for determining levels of cold hardiness during the transition periods.

Dehydrin accumulation during cold acclimation in bark tissues (Arora and Wisniewski, 1994), which survive freezing stress by toler- ating freeze-induced dehydration, is consistent with the putative role of these proteins. However, the observed association between seasonal accumulation and disappearance of dehydrin protein and cold acclimation capacity of peach xylem tissues is intriguing. Cold acclimation in these tissues is generally explained in relation to their ability to exhibit deep supercooling (Ashworth et al., 1983; Wisniewski, 1995), whereby living cells of xylem survive freezing stress by avoiding the dehydrative effects of extracellular ice. If dehydrins are specifically induced in response to environmental cues that signal dehydrative stress as is generally believed (Close et al., 1993), our results suggest that xylem tissues of peach undergo cellular dehydration during cold acclimation. This view is supported by the observation of microvacuolation in xylem parenchyma cells during cold acclimation (Wisniewski and Ashworth, 1986). Based on the above observations, we speculate that peach xylem tissues may not fit entirely into the supercooling category but may possess an alternative mechanism of survival that could include some cellular dehydration. Ristic and Ashworth (1993) noted that xylem ray parenchyma cells of supercooling Cornus florida $\mathrm{L}$. appeared to be injured due to intracellular ice formation and cavitation, whereas Malone and Ashworth(1991) noted that xylem parenchyma of Cornus sericea L. (nonsupercooling species) did not undergo cell collapse (cytorrhysis) in response to extracellular freezing and cellular dehydration, as expected. Gusta et al. (1983) also noted the ability of several species of woody plants whose xylem tissues exhibit deep supercooling to cold-acclimate below the homogeneous nucleation temperature of water and suggested that the xylem tissues were able to dehydrate and lower the freezing point. Collectively, these conclusions suggest that more comprehensive studies are warranted to fully understand the complex freezing behavior of xylem tissues of woody perennials.

\section{Literature Cited}

Arora, R. and M.E. Wisniewski. 1994. Cold acclimation in genetically related (sibling) deciduous and evergreen peach [Prunus persica (L.) Batsch]. II. A 60-kilodalton bark protein in cold acclimated tissues of peach is heat-stable and related to the dehydrin family of proteins. Plant Physiol. 105:95-101.

Arora, R., M.E. Wisniewski, and R. Scorza. 1992. Cold acclimation in genetically related (sibling) deciduous and evergreen peach [ Prunus persica (L.) Batsch]. I. Seasonal changes in cold hardiness and polypeptides of bark and xylem tissues. Plant Physiol. 99:1562-1568.

Ashworth, E.N., D.J. Rowse, and L.A. Billmyer. 1983. The freezing of water in woody tissues of apricot and peach and the relationship of freezing injury. J. Amer. Soc. Hort. Sci. 108:299303.

Ashworth, E.N. and M.E. Wisniewski. 1991. Response of fruit tree tissues to freezing temperatures. HortScience 26:501-504.

Burke, M.J. 1979. Water in plants: The phenomenon of frost survival, p. 259-289. In: L.S. Underwood, L.L. Tieszen, A.B. Callahan, and G.E. Folk (eds.). Comparative mechanisms of cold adaptation. Academic, New York. 
Close, T.J., R.D. Fenton, A. Yang, R. Asghar, D.A DeMason, D.E. Crone, N.C. Meyer, and F. Moonan. 1993. Dehydrin: The protein, p. 104114. In: T.J. Close and E.A. Bray (eds.). Plant responses to cellular dehydration during environmental stress. Current topics in plant physiology: An American Society of Plant Physiologists series, Rockville, Md.

George, M.F., M.R. Becwar, and M.J. Burke. 1982. Freezing avoidance by deep undercooling of tissue water in winter-hardy plants. Cryobiology 19:628-639.

Gusta, L.V, M.J. Tyler, and T.H. Chen. 1983. Deep undercooling in woody taxa growing north of the $-40^{\circ} \mathrm{C}$ isotherm. Plant Physiol. 72:122-128.

Malone, S.R. and E.N. Ashworth. 1991. Freezing stress response in woody tissues observed using low-temperature scanning electron microscopy and freeze substitution techniques. Plant Physiol. 95:871-881.

Muthalif, M.M. and L.J. Rowland. 1994. Identification of dehydrin-like proteins responsive to chilling in floral buds of blueberry. Plant Physiol. 104:1439-1447.

Quamme, H.A. 1976. Relationship of the low temperature exotherm to apple and pear production in North America. Can. J. Plant Sci. 56:493500

Ristic, Z. and E.N. Ashworth. 1993. Ultrastructura evidence that intracellular ice formation and possibly cavitation are the sources of freezing injury in supercooling wood tissue of Cornus florida L. Plant Physiol. 103:753-761.

Wisniewski, M. 1995. Deep supercooling in woody plants and the role of cell wall structure, p. 163181. In: R.E. Lee, Jr., C.J. Warren, and L.V. Gusta (eds.). Biological ice nucleation and its applications. APS Press, St. Paul, Minn.

Wisniewski, M. and R. Arora. 1993. Adaption and response of fruit trees to freezing temperatures, p. 299-320. In: A.R. Biggs (ed.). Cytology, histology, and histochemistry of fruit tree diseases. CRC Press, Boca Raton, Fla.

Wisniewski, M. and E.N. Ashworth. 1986. A comparison of seasonal ultrastructural changes in stem tissues of peach that exhibit contrasting mechanisms of cold acclimation. Bot. Gaz. $147: 407-417$ 